\title{
Article
}

Arq Neuropsiquiatr 2010;68(2):194-197

\section{Homozygotic intronic GAA mutation in three siblings with late-onset Pompe's disease}

\author{
Anderson Kuntz Grzesiuk?, Sueli Mieko Oba Shinjo², Roseli da Silva², \\ Marcela Machado ${ }^{3}$, Marcial Francis Galera ${ }^{4}$, Suely Kazue Nagahashi Marie²
}

\begin{abstract}
Pompe's disease (PD) is a metabolic myopathy caused by the accumulation of lysosomal glycogen, secondary to acid $\alpha$-glucosidase (GAA) enzyme deficiency. Childhood and lateonset forms are described, differing by the age of onset and symptoms. In this study were analyzed affected siblings with Pompe's disease (PD) and their distinct clinical and pathological presentations. Method: Diagnosis was performed by the clinical presentation of limb-girdle dystrophies and respiratory compromise. Confirmatory diagnoses were conducted by muscle biopsy, GAA activity measurement and by GAA gene genotyping. Results: The findings suggested muscular involvement due to GAA deficiency. GAA genotyping showed they are homozygous for the c.-32-3C>A mutation. Conclusion: Herein we reported a family where three out of five siblings were diagnosed with late-onset PD, although it is a rare metabolic disease inherited in an autossomal recessive manner. We emphasize the importance of including this presentation within the differential diagnoses of the limb-girdle dystrophies once enzyme replacement therapy is available.
\end{abstract}

Key words: glycogen storage disease type II, mutation, Pompe disease.

Mutação homozigótica intrônica no gene GAA em três irmãos com doença de Pompe de início tardio

\section{RESUMO}

A doença de Pompe (DP) é uma miopatia originada do acúmulo lisossomal de glicogênio, devido à deficiência da enzima $\alpha$-glicosidase ácida (GAA), sendo descritas formas de inicio precoce e tardio. Neste estudo analisamos retrospectivamente o perfil clinico e patológico de 3 irmãos portadores de doença de Pompe de inicio tardio. Método: $\bigcirc$ diagnóstico foi realizado mediante apresentação clinica de distrofia de cinturas associado a comprometimento respiratório, sendo confirmado por biópsia muscular e análise da atividade e genotipagem da GAA. Resultados: Os exames clínicos e laboratoriais demonstram envolvimento muscular devido à deficiência da GAA, com uma mutação c.32-3C>A em homozigose. Conclusão: Relatamos os aspectos clínicos e laboratoriais de 3 irmãos afetados por doença de Pompe de início tardio. Enfatizamos a importância de incluir esta patologia no diagnóstico diferencial das distrofias de cinturas, uma vez que para esta patologia específica existe a possibilidade terapêutica através de reposição enzimática. Palavras-chave: doença de Pompe, mutação, glicogenose.

\section{Correspondence} Anderson Kuntz Grzesiuk Rua Custódio de Mello 630 / 103 78030-435 Cuiabá MT - Brasil E-mail: neuroakg@terra.com.br

Received 27 August 2009 Received in final form 16 October 2009 Accepted 28 November 2009
Pompe's disease (PD), also known as acid maltase deficiency, is a glycogen storage disease type II. It is a metabolic myopathy caused by the accumulation of lys- osomal glycogen, inherited as a recessive disorder ${ }^{1}$. It was first described in 1932 by the Dutch pathologist Johannes Cassianus Pompe, in a female child who died at 7 
months of age due to hypertrophic cardiomyopathy, considered to be idiopathic at that time. In 1963, Hers and cols. described the acid $\alpha$-1,4-glucosidase (GAA) enzyme within the lysosomes, and correlated its deficiency with $\mathrm{PD}^{2}$.

Classical or early-onset PD is characterized by global hypotonia (floppy infant), marked cardiomyopathy, in children with less than 2 years of age. Subsequently, patients older than 2 year-old presenting progressive muscular weakness, as in limb-girdle muscular dystrophy, without cardiomyopathy were classified as late-onset PD. These patients may also present spine deformities, and respiratory compromise due to intercostal muscles, and diaphragm weakness. The final phenotype is in part modulated by the GAA enzymatic activity, which is completely deficient in early-onset cases, and partially deficient in late-onset cases. The progression of the disease is inexorable in early-onset PD, and death overcome within the first two years of life. On the other hand, phenotypic heterogeneity is related to variable quantity of residual GAA activity in late-onset cases ${ }^{3}$. This natural history of PD, specially in early-onset form, has been modified by introduction of the human recombinant GAA (hrGAA) enzymatic replacement therapy (ERT), approved by the American Food and Drug Administration on February, 2008. Survival time has been extended in early-onset $\mathrm{PD}^{4,5}$, and although the follow-up time for late-onset $\mathrm{PD}$ is not yet long enough to any consistent observation, some improvement of motor and respiratory functions have been observed ${ }^{6,7}$. Correct diagnosis of PD becomes mandatory, once a specific treatment is now available. It is also important to retrieve underdiagnosed late-onset PD among those presenting LGMD-like phenotype $e^{8-10}$.

Therefore, the aims of the present study are: (1) report three siblings presenting LGMD-like phenotype with lateonset PD, and (2) present an intronic GAA gene mutation in homozigosity, a condition not reported previously.

\section{METHOD}

Three siblings from a family of five children were analyzed retrospectively. Electroneuromyography (ENMG), spirometry, polysomnography, and measurements of creatine phosphokinase (CK) and GAA activity in dry-blood spot $^{11}$ were analyzed. Muscular biopsy was performed in two patients. GAA gene genotyping was studied as reported previously ${ }^{12}$, and briefly was done as follows: genomic peripheral blood DNA samples had the coding region and the intron/exon boundaries of the GAA gene amplified by PCR and subsequently sequenced on an ABI PRISM 3130 DNA Sequencer using BigDye v.3.1 (Applied Biosystem, Foster City, CA).

The study was approved by the Ethics Committee of Santa Rosa Hospital, and all members of the family studied signed an informed consent.

\section{RESULTS}

In a family of five siblings, three, one female, and two males, 47, 43 and 45 years of age, presented difficulties in climbing stairs, standing-up, and frequent drops starting on thirties (Table). Limb-girdle muscular dystrophy was the diagnosis attributed to them, based on elevated serum level of CK (Table), muscle biopsy, and ENMG performed in two of them showing nonspecific atrophic alterations, and myopathic pattern, respectively. The correct diagnosis was only established after six years from the onset of symptoms in the oldest sister (Case 1), who started presenting dyspnea at mild efforts. Restrictive ventilatory disturbance was detected on spirometry. She evolved to respiratory failure in the following year, and required invasive mechanic ventilation with continuous Bi-Pap through a tracheostomy. The association of proximal limb-girdle muscle weakness, mainly in lower limbs, to weakness of respiratory muscle lead to the hypothesis of PD, which was confirmed by GAA enzymatic mea-

Table. Findings in a family.

\begin{tabular}{|c|c|c|c|c|c|c|c|c|c|c|c|}
\hline \multirow[b]{2}{*}{$\begin{array}{l}\text { Case } \\
\text { Gender }\end{array}$} & \multirow{2}{*}{$\begin{array}{l}\text { Onset of } \\
\text { symptoms } \\
\text { (years) }\end{array}$} & \multirow{2}{*}{$\begin{array}{c}\text { Age at } \\
\text { diagnosis } \\
\text { (years) }\end{array}$} & \multirow{2}{*}{$\begin{array}{l}\text { Actual } \\
\text { age } \\
\text { (years) }\end{array}$} & \multirow[b]{2}{*}{$\begin{array}{c}\text { ERT } \\
\text { (months) }\end{array}$} & \multicolumn{2}{|c|}{ Clinical findings } & \multirow[b]{2}{*}{$\begin{array}{l}\text { Respiratory } \\
\text { function }\end{array}$} & \multirow[b]{2}{*}{ ENMG } & \multirow[b]{2}{*}{$\begin{array}{c}\text { CK } \\
(26-155 \mathrm{U} / \mathrm{I})\end{array}$} & \multicolumn{2}{|c|}{ GAA activity } \\
\hline & & & & & $\begin{array}{c}\text { Site of } \\
\text { weakness }\end{array}$ & MRC & & & & $\begin{array}{c}\text { Inhibition \% } \\
(<40 \%)\end{array}$ & $\begin{array}{c}\mathrm{N} / \mathrm{A} \\
(<40)\end{array}$ \\
\hline $\begin{array}{l}1 \\
F\end{array}$ & 32 & 46 & 47 & 12 & LGM & III & BIPAP & Myopathic & 197 & 87.02 & 43.54 \\
\hline $\begin{array}{l}2 \\
M\end{array}$ & 31 & 40 & 43 & 12 & LGM & III/IV & $\begin{array}{c}\text { Obstructive } \\
\text { apnea }\end{array}$ & Myopathic & 1449 & 89.0 & 52.24 \\
\hline $\begin{array}{l}3 \\
M\end{array}$ & 43 & 44 & 45 & 12 & LGM & IV & $\begin{array}{c}\text { Moderate } \\
\text { Restrictive } \\
\text { disorder }\end{array}$ & Normal & 673 & 91.6 & 55.71 \\
\hline
\end{tabular}

F: female; M; male; ERT: enzymatic replacement therapy; LGM: limb-girdle muscle; MRC: scale of muscle strength testing according to Medical Research Council; ENMG, electroneuromyography; CK, creatine phosphokinase; N/A: ration between neutral and acid GAA. 
surement in dry blood spot (Table), and GAA genotyping. This diagnosis was also confirmed in the other two sibs (Cases 2 and 3 ) by both biochemichal and molecular methods. Although the brothres presented no clinical respiratory complaint, further investigation of respiratory function by polysomnography and spirometry revealed obstructive apnea, and moderate restrictive disorder, respectively (Table). All three affected sibs presented the intron 1 (c.-32-3C>A) mutation in GAA gene in homozygosis. Each parent presented this mutation in one of the alleles, and it was not detected in the other two asymptomatic sibs. hrGAA ERT was started upon the confirmation of $\mathrm{PD}$, and they have received the medication for a period of one year. Clinical and laboratorial followups have been done regularly to monitor disease evolution and response to therapy.

\section{DISCUSSION}

We report a family with three affected siblings with late-onset $\mathrm{PD}$, harboring an intronic mutation in homozigozity, a condition not described previously. It is interesting to emphasize the intrafamiliar phenotypic heterogeneity. Although the onset of symptoms was similar among them, around their thirties, they presented different degree of respiratory compromise. Sibling phenotype discordance in late-onset PD has been described by others, where 10 years difference in age of onset between affected sibs or different clinical symptoms were detected, attesting a spectrum of clinical presentation even in a similar genetic background as in a single sibship ${ }^{13,14}$. Other non-genetic factors as lifestyle, nutrition, other genetic modifiers, and environmental factors might contribute to explain such clinical inter and intra-familiar variability.

The present report also stresses the importance of considering late-onset PD among the differential diagnosis of limb-girdle muscle weakness ${ }^{15-17}$. As the reliability of $\mathrm{CK}$ level is low, since values vary broadly in $\mathrm{PD}^{8}$, and muscle biopsy may be normal in up to $30 \%$ in late-onset $\mathrm{PD}^{18}$, more specific testing is fundamental for the diagnosis. The first screening for PD could be done by GAA enzymatic measurement in dried blood spot, with results obtained in 1-2 days ${ }^{11}$. Then, the confirmation of PD diagnosis should be complemented by GAA biochemical assay in fibroblast cells or skeletal muscle sample or genotyping that are more costly and requires longer period of time for the results ${ }^{17}$.

The correct diagnosis of PD is fundamental as specific treatment is currently available. GAA enzymatic replacement therapy (ERT) has been proved to be well tolerated. Although the follow-up time since the introduction of ERT in our patients is still short to allow any conclusion, no evolvement of the clinical findings were observed. Longer follow-up of the present cases will fur- ther contribute to evaluate the response to ERT in late-onset PD.

The homozygotic c.32-3C>A intron 1 mutation detected in affected sibs is an inedit contribution, as this condition has not previously reported. This c.-32-3C >A mutation was recently described by our group and others ${ }^{12,19,20}$, and it leads to a deletion of $579 \mathrm{bp}$, predicting an anomalous transcript which would translate into a shorter peptide lacking the first 182 amino acids of the protein (p.M1_T182) comprising the 27 residues of signal sequence, the 42 residues of the propeptide and the first 113 amino acids of the mature protein (from 70 to 182). Thus, factors which control splice site selection may contribute to the relative normal transcript level generated by the mutant allele, possibly explaining the absence of symptoms up to three decades in our patients. This mutation has been described in combinantion with a missense mutation, c.1655T $>C$, in an early-onset $\mathrm{PD}^{21}$, and with c.1447G $>$ A missense mutation, in late-onset PD by our group ${ }^{11}$. However, a homozygotic condition of a intronic mutation might be rare, as such a condition was not yet detected even for the most common intronic c.31-13T>G mutation in late-onset $\mathrm{PD}^{3,21}$.

In summary, this is the first description of a homozygotic intronic GAA mutation in three siblings of late-onset Pompe's disease presenting a limb-girdle muscle weakness associated to variable degree of respiratory disfunction.

\section{REFERENCES}

1. Winkel LPF, Hagemans MLC, Van Doorn PA, et al. The natural course of nonclassic Pompe's disease: a review of 225 published cases. J Neurol 2005;252: 875-884.

2. Baethmann M, Straub V, Reuser AJ. Pompe disease. Bremen:Uni-Med Verlag AG, 2008;103:12-14

3. Hirschhorn R. Glycogen storage disease type II (GSD II). In: Scriver CR, Beau$\operatorname{det} A L$, Sly WS, Valle D (Eds). The metabolic and molecular bases of inherited disease. New York: MacGraw-Hill, 2001:3389-3420.

4. Kishnani PS, Corzo D, Nicolino M, et al. Recombinant human acid[alpha]-glucosidase: major clinical benefits in infantile-onset Pompe disease. Neurology 2007:68:99-109.

5. Pereira SJ, Berditchevisky, Marie SK. Report of the first Brazilian infantile Pompe disease patient to be treated with recombinant human acid alpha-glucosidase. J Pediatr 2008:84:272-275.

6. Winkel LP, Van den Hout JM, Kamphoven JH, et al. Enzyme replacement therapy in late-onset Pompe's disease: a three-year follow-up. Ann Neurol 2004; 55:495-502

7. Case LE, Koeberl DD, Young SP, et al. Improvement with ongoing enzyme replacement therapy in advanced late-onset Pompe disease: a case study. Mol Gene Metab 2008:95;233-235.

8. Laforet $\mathrm{P}$, Nicolino $\mathrm{M}$, Eymard $\mathrm{B}$, et al. Juvenile and adult onset acid maltase deficiency in France: genotype-phenotype correlation. Neurology 2000;55: 1122-1128

9. Hagemans ML, Winkel LP, Van Doorn PA, et al. Clinical manifestation and natural course of late-onset Pompe's disease in 54 Dutch patients. Brain 2005; 128:671-677.

10. American association of neuromuscular \& electrodiagnostic medicine. Diagnostic criteria for late-onset (childhood and adult) pompe disease. Muscle Nerve 2009;40:149-160.

11. Chamoles NA, Niizawa G, Blanco M, Gaggioli D, Casentini C. Glycogen storage disease type II: enzymatic screening in dried blood spots on filter paper. Clin Chim Acta 2004:347:97-102. 
12. Oba-Shinjo SM, da Silva R, Andrade FG, et al. Pompe disease in a Brazilian series: clinical and molecular analyses with identification of nine new mutations. J Neurol 2009;256:1881-1890.

13. ten Berg KMG, Beemer FA, Wokke JH. Phenotypic expression of late-onset glycogen storage disease type II: identification of asymptomatic adults through family studies and review of reported families. Neuromuscul Disord 2000;10: 467-471.

14. Zlotogora J. Intrafamilial variability in lysosomal storage diseases. Am J Med Genet 1987;27:633-638.

15. Muller-Felber W, Horvath R, Gempel K, et al. Late onset Pompe disease: clinical and neurophysiological spectrum of 38 patients including long-term follow-up in 18 patients. Neuromusc Disord 2007;17:698-706.

16. Wokke JH, Escolar DM, Pestronk A, et al. Clinical features of late-onset Pompe disease: A prospective cohort study. Muscle Nerve 2008;38:1236-1245.

17. Llerena JC Jr, Horovitz DM, Marie SK, et al. Brazilian Network for Studies in
Pompe Disease (ReBrPOM). The Brazilian consensus on the management of Pompe disease. J Pediatr 2009;155(Suppl 4):S47-S56.

18. Saux A, Laforet P, Pagès AM, et al. Forme adulte de la maladie de Pompe: à propos de six cas de la région Du Languedoc-Roussillon. Rev Neurol 2008; 164:336-342.

19. Pittis MG, Donnarumma M, Montalvo AL, et al. Molecular and functional characterization of eight novel GAA mutations in Italian infants with Pompe disease. Hum Mutat 2008,29:27-36.

20. Kroos M, Pomponio RJ, Van Vliet L, et al and de GAA Database Consortium. Update of the Pompe Disease mutation database with 107 sequence variants and a format for severity rating. Hum Mutat 2008;29:13-26.

21. Huie ML, Chen AS, Tsujino S, et al. Aberrant splicing in adult onset glycogen storage disease type II (GSDII): molecular identification of an IVS1 (-13T->G) mutation in a majority of patients and a novel IVS10 (+1GT->CT) mutation. Hum Mol Genet 1994, 3:2231-2236. 